\title{
THE RELATIONSHIP BETWEEN THERMAL TREATMENT OF SERPENTINE AND ITS REACTIVITY
}

\author{
ODVISNOST MED TOPLOTNO OBDELAVO SERPENTINA IN \\ NJEGOVO AKTIVNOSTJO
}

\author{
Gabriel Sučik ${ }^{1}$, Adriana Szabóová ${ }^{1}$, L'uboš Popovič ${ }^{1}$, Damir Hršak ${ }^{2}$ \\ ${ }^{1}$ Technical University of Kosice, Faculty of Metallurgy, Department of Ceramics, Park Komenského 3, 04200 Kosice, Slovakia \\ ${ }^{2}$ University of Zagreb, Faculty of Metallurgy, Aleja narodnih heroja, 44103 Sisak, Croatia \\ gabriel.sucik@tuke.sk \\ Prejem rokopisa - received: 2014-09-09; sprejem za objavo - accepted for publication: 2015-02-04
}

doi:10.17222/mit.2014.222

\begin{abstract}
In this research the effect of the thermal treatment of chrysotile serpentine on the increase in the reactivity during the process of its leaching in a diluted hydrochloric acid was investigated. Measurements were made on samples of $5 \mathrm{~g}$ taken from the heap by selecting the fractions of $3-5 \mathrm{~mm}$. The calcination in air of individual samples, required for the analysis, was carried out in an electric muffle furnace at temperatures from 500 to $1100{ }^{\circ} \mathrm{C}$ at intervals of $50{ }^{\circ} \mathrm{C}$. The specific surface areas of the calcined samples were measured with the multipoint B.E.T. method and the relative density with a mercury high-pressure porosimeter. The results were related with the yield of $\mathrm{Mg}^{2+}$ in an extract of $1 \mathrm{~g}$ of a ground serpentine fraction from 0 to $315 \mu \mathrm{m}$ in $250 \mathrm{~cm}^{3}$ of $0.25 \mathrm{M} \mathrm{HCl}$, taken after $5 \mathrm{~min}$ from a reactor stirred at $500 \mathrm{~min}^{-1}$ and at $20{ }^{\circ} \mathrm{C}$. The strong relation between the temperature of the serpentinite calcination and the rate of leaching was confirmed. The specific surface area of the examined serpentine rose from $16.2 \mathrm{~m}^{2} \mathrm{~g}^{-1}$ at a calcination temperature of $600{ }^{\circ} \mathrm{C}$ to the maximum value of $45.2 \mathrm{~m}^{2} \mathrm{~g}^{-1}$ at a calcination temperature of 700 ${ }^{\circ} \mathrm{C}$. At this temperature, the degree of dehydroxylation was $82 \%$ and, at the same time, the maximum rate of dissolution of $\mathrm{Mg}^{2+}$ was reached. Above this temperature, the specific surface area decreased and, at a temperature of $1100^{\circ} \mathrm{C}$, it fell to a value of $2 \mathrm{~m}^{2} \mathrm{~g}^{-1}$, which also resulted in a reduction of the yield of $\mathrm{Mg}^{2+}$.

Keywords: serpentinite, calcination, specific surface area, apparent porosity, leaching rate, crystallinity
\end{abstract}

V tem članku je bil preiskovan vpliv toplotne obdelave krizotil serpentina na povečanje reaktivnosti pri procesu izločanja iz raztopine solne kisline. Meritve so bile izvršene na $5 \mathrm{~g}$ vzorcih, vzetih na odlagališču, z ločitvijo frakcije $3-5 \mathrm{~mm}$. Kalcinacija na zraku, posameznih vzorcev za analizo, je bila izvršena v električni retortni peči pri temperaturah od $500{ }^{\circ} \mathrm{C}$ do $1100{ }^{\circ} \mathrm{C}$, v intervalih po $50{ }^{\circ} \mathrm{C}$. Specifična površina kalciniranih vzorcev je bila izmerjena z večtočkovno B.E.T. metodo, relativna gostota pa z živo-srebrnim visoko-tlačnim porozimetrom. Rezultati so bili primerjani z izkoristkom $\mathrm{Mg}^{2+}$ pri ekstrakciji iz $1 \mathrm{~g}$ osnovne frakcije serpentina $\mathrm{z}$ zrnatostjo 0 do $315 \mu \mathrm{m}$ v $250 \mathrm{~cm}^{3} 0,25 \mathrm{M} \mathrm{HCl}$, vzeti po 5 min iz reaktorja s hitrostjo mešanja 500 min ${ }^{-1}$ pri $20{ }^{\circ} \mathrm{C}$. Potrjena je bila močna odvisnost med temperaturo kalcinacije serpentina in hitrostjo izločanja. Specifična površina preiskovanega serpentina je narasla iz $16,2 \mathrm{~m}^{2} \mathrm{~g}^{-1}$ pri temperaturi kalcinacije $600{ }^{\circ} \mathrm{C}$ na največjo vrednost $45,2 \mathrm{~m}^{2} \mathrm{~g}^{-1} \mathrm{pri}^{\circ}$ temperaturi kalcinacije $700{ }^{\circ} \mathrm{C}$. Pri tej temperaturi je bila stopnja dehidroksilacije $82 \%$ in istočasno je bila dosežena tudi največja hitrost raztapljanja $\mathrm{Mg}^{2+}$. Nad to temperaturo se je specifična površina zmanjšala in pri temperaturi $1100{ }^{\circ} \mathrm{C}$ padla na $2 \mathrm{~m}^{2} \mathrm{~g}^{-1}$, kar je vplivalo tudi na zmanjšanje izkoristka $\mathrm{Mg}^{2+}$.

Ključne besede: serpentinit, kalcinacija, specifična površina, navidezna poroznost, hitrost izločanja, kristaliničnost

\section{INTRODUCTION}

The economic efficacy of chemical technologies is closely related with the production speed. The raw material, the subject of this paper and also of earlier papers, is the waste micro-chrysotile material from the Dobšiná area (Slovakia). The aim of the chemical treatment is the production of chemically pure magnesium compounds ${ }^{1}$, silica $^{2-4}$ and ferric hydroxide ${ }^{5}$. In the previous papers ${ }^{6-8}$, the following leaching agents were tested: hydrochloric acid, acetic acid and ammonium chloride. The effect of the leaching-agent concentration and the temperature on the kinetics of the leaching of crude serpentine was monitored.

The impacts of the thermal-treatment calcination, where the key parameters were the degree of conversion and the temperature of the dehydroxylation of serpentine, were examined in previous papers ${ }^{9-14}$. According to these papers, the calcination of serpentine of up to $80 \%$ resulted in an up to 30-time acceleration of the transfer of $\mathrm{Mg}^{2+}$ in the solution compared to the leaching of crude serpentine. The rapidity is attributed to the destruction of the layers of magnesium octahedron and the release of internal links. In addition, there are also changes in the specific surface area and bulk density, relating to the porosity ${ }^{15}$. These parameters are directly measurable and, in contrast to the qualitative parameter change in the crystallinity, they may be related to the kinetic parameters of the chemical reactions of the solidus-liquidus type, where the control process is the reaction at the phase interface.

\section{EXPERIMENTAL WORK}

The measurements of the specific-surface-area and density criteria were implemented on fractions of 3-5 $\mathrm{mm}$. The apparent/open porosity was measured on sam- 
ples with a cube shape and a volume of $0.2-0.5 \mathrm{~cm}^{3}$. For the chemical and thermal analysis, the samples were ground in a Mn-steel spherical vibrating chamber. The chemical composition of serpentine was analyzed with ICP OES iCAP6300 and the results are summarized in Table 1. By heating the crude serpentine, the thermal dissociation to the origin of the so-called topotactic structure $^{16}$ of serpentine anhydride ${ }^{17}$ (Equation (1)) occurs in a temperature range of $540-660{ }^{\circ} \mathrm{C}$, which is characterized by a low chemical stability and is accompanied by an increase in the specific surface area and porosity:

$$
\mathrm{Mg}_{3} \mathrm{Si}_{2} \mathrm{O}_{5}(\mathrm{OH})_{4}(\mathrm{~s}) \underset{\left[3 \mathrm{MgO}+2 \mathrm{SiO}_{2}\right](\mathrm{s})+2 \mathrm{H}_{2} \mathrm{C}-660^{\circ} \mathrm{O}}{\longrightarrow}
$$

chrysotile

$$
\text { topotactic structure of oxides water }
$$

By heating them to above $700{ }^{\circ} \mathrm{C}$, the $\mathrm{MgO}$ and $\mathrm{SiO}_{2}$ oxides react with each other on a stable forsterite and amorphous silica ${ }^{17}$, stabilizing the structure and increasing the resistance to acids. The chemical reaction is expressed with Equation (2):

$$
2\left[3 \mathrm{MgO}+2 \mathrm{SiO}_{2}\right](\mathrm{s}) \stackrel{2700^{\circ} \mathrm{C}}{\longrightarrow} \mathrm{Mg}_{2} \mathrm{SiO}_{4}(\mathrm{~s})+\mathrm{SiO}_{2}(\mathrm{~s})
$$

topotactic structure of oxides forsterite amorphous silica

Table 1: Chemical composition of SED serpentine Tabela 1: Kemijska sestava SED serpentina

\begin{tabular}{|c|c|c|c|c|c|c|}
\hline $\mathrm{MgO}$ & $\mathrm{SiO}_{2}$ & $\mathrm{Al}_{2} \mathrm{O}_{3}$ & $\mathrm{CaO}$ & $\mathrm{Fe}_{2} \mathrm{O}_{3}$ & $\mathrm{NiO}$ & L.O.I. \\
\hline 47.8 & 28.6 & 2.4 & 0.9 & 5.9 & 0.3 & 12.57 \\
\hline
\end{tabular}

The thermochemical processes are identified with a differential thermal analysis and a NETZSCH STA 449F3 Jupiter thermogravimetric instrument, and evaluated in the NETZSCH Proteus program. A graphic recording with characteristic temperature points is shown in Figure 1 and used for setting the experimental conditions of the calcination.

The calcination in air of $5 \mathrm{~g}$ samples of coarse fractions of 3-5 mm was carried out under controlled conditions in an electric muffle furnace at $500-1100{ }^{\circ} \mathrm{C}$, with

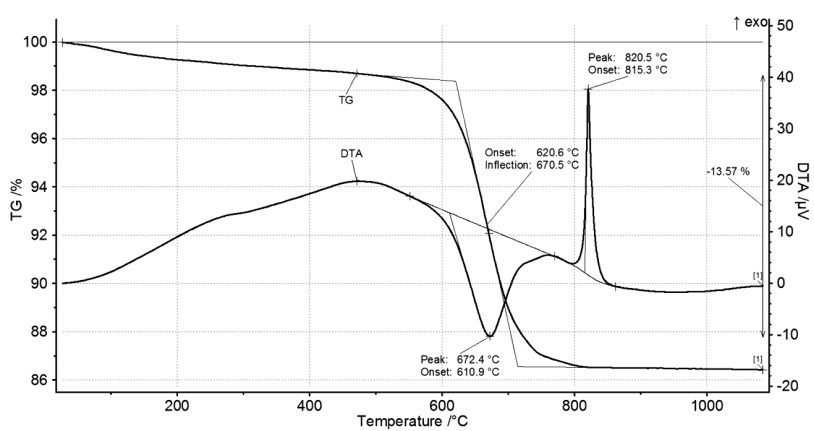

Figure 1: Differential thermal and thermogravimetric analysis of crude serpentine

Slika 1: Diferenčna termična in termogravimetrična analiza surovega serpentina increments of $50{ }^{\circ} \mathrm{C}$ and a dwell time at a particular temperature of $180 \mathrm{~min}$. The samples were inserted into the cold furnace and heated at a rate of $15^{\circ} \mathrm{C}$ per minute. With this procedure, 13 samples (SED500- SED1100) were prepared. After the annealing procedure, the residual loss due to annealing (the degree of conversion) and dimensional changes were determined. In the first step of the analysis, the weight and moisture content of each sample were determined on a KERN MLB 50-3N thermobalance, and the geometric volume of mercury was determined on an Amsler 9/593 volume meter. The pore size distribution and the open porosity of the samples were measured with the method of highpressure mercury porosimetry using automatic Quantachrome porosimeter Poremaster 33. The specific surface areas of $S_{\mathrm{A}}$ samples were measured with a surface-andpore analyzer through the sorption of nitrogen, with the B.E.T. method. The results were compared with the parameters of the reference sample of unannealed serpentine (SEDraw).

\section{RESULTS AND DISCUSSION}

The measurement of open porosity $\pi_{\mathrm{a}}$ of calcined samples SED500 to SED1100 did not confirm the expected correlation between the chemical reactivity in terms of the leaching rate of $\mathrm{Mg}^{2+}$ and $\pi_{\mathrm{a}}$. It can be claimed that the maximum $\pi_{\mathrm{a}}$ of almost $20 \%$ was measured on the samples exposed to the temperatures of the forsterite formation with the maximum rate of around $900{ }^{\circ} \mathrm{C}$, with the increase from the temperature of $700{ }^{\circ} \mathrm{C}$ in accordance with the forsterite formation ${ }^{17}$. On the contrary, at the temperatures in the area of dehydroxylation, $\pi_{\mathrm{a}}=1.5 \%$ at the level of raw serpentinite (SEDraw). Intragranular pores had the major proportion, up to $2 / 3$ $\boldsymbol{\pi}_{\mathrm{a}}$, as shown in Figure 2 .

The only noticeable consistency between $\pi_{\mathrm{a}}$ and specific surface area $S_{\mathrm{A}}$ is the local minimum of $1.5 \%$ and $16 \mathrm{~m}^{2} \mathrm{~g}^{-1}$ at $600{ }^{\circ} \mathrm{C}$, which could be explained with the closing of the pores due to the impact of the oxi-

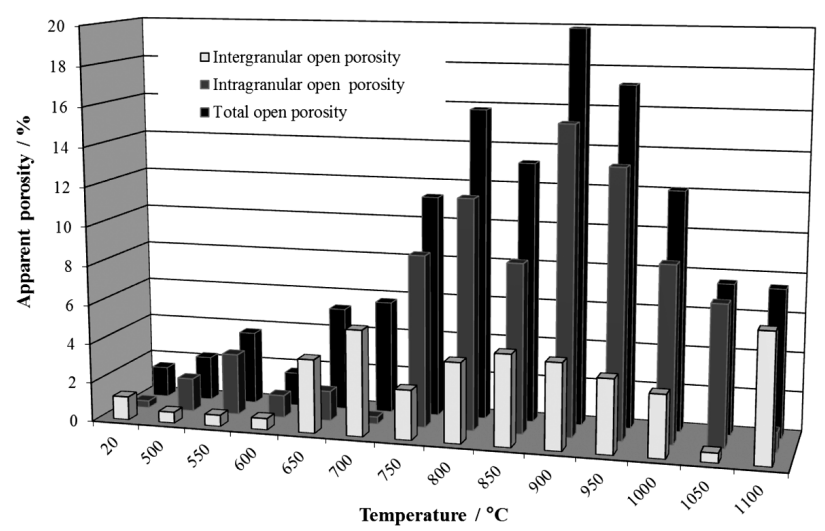

Figure 2: Open porosity and pore character depending on the calcination temperature of SED

Slika 2: Odprta poroznost in značilnost por v odvisnosti od temperature kalcinacije SED 


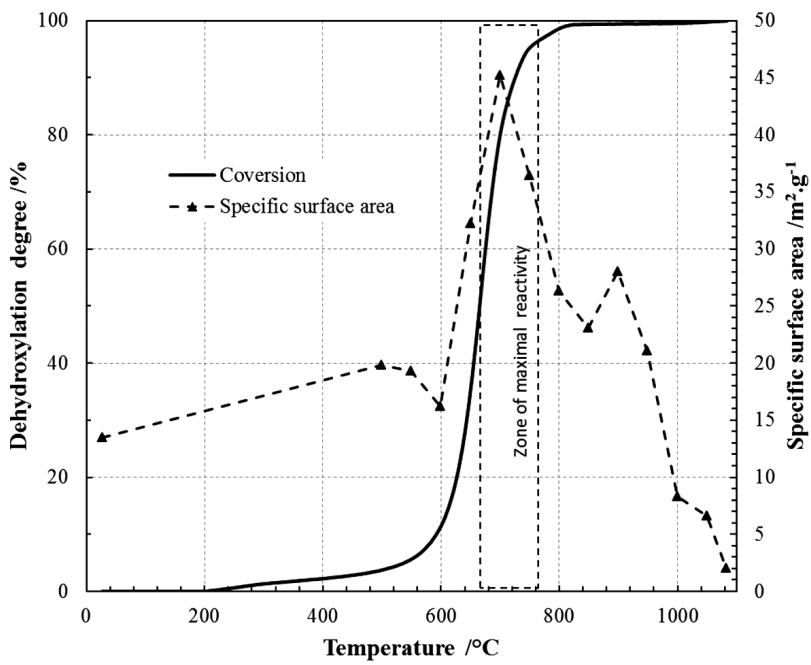

Figure 3: Change in the specific surface of SED depending on the calcination temperature

Slika 3: Spreminjanje specifične površine SED, v odvisnosti od temperature kalcinacije

dizing reactions of $\mathrm{Fe}^{2+} \rightarrow \mathrm{Fe}^{3+}$. Strong correlations between the degree of conversion $\alpha$ and $S_{\mathrm{A}}$ can be found in Figure 3. The maximum $S_{\mathrm{A}}$ of $45.2 \mathrm{~m}^{2} \mathrm{~g}^{-1}$ was measured for sample SED700 with $\alpha=82 \%$. Increasing the temperature over the recrystallization temperature causes sintering, which is shown as a decrease in $\pi_{\mathrm{a}}$ and $S_{\mathrm{A}}$ over the value of $2 \mathrm{~m}^{2} \mathrm{~g}^{-1}$.

The reactivity of ground calcinate was tested for fractions of $0-315 \mu \mathrm{m}$. Figure 4 shows a graphical representation of the function of the yield of $\mathrm{Mg}^{2+} \alpha_{\mathrm{Mg}}=$ $f(\alpha, T)$ in intervals of $(10,20$ and 60$) \mathrm{min}$. From this dependence it follows that for the maximum efficiency

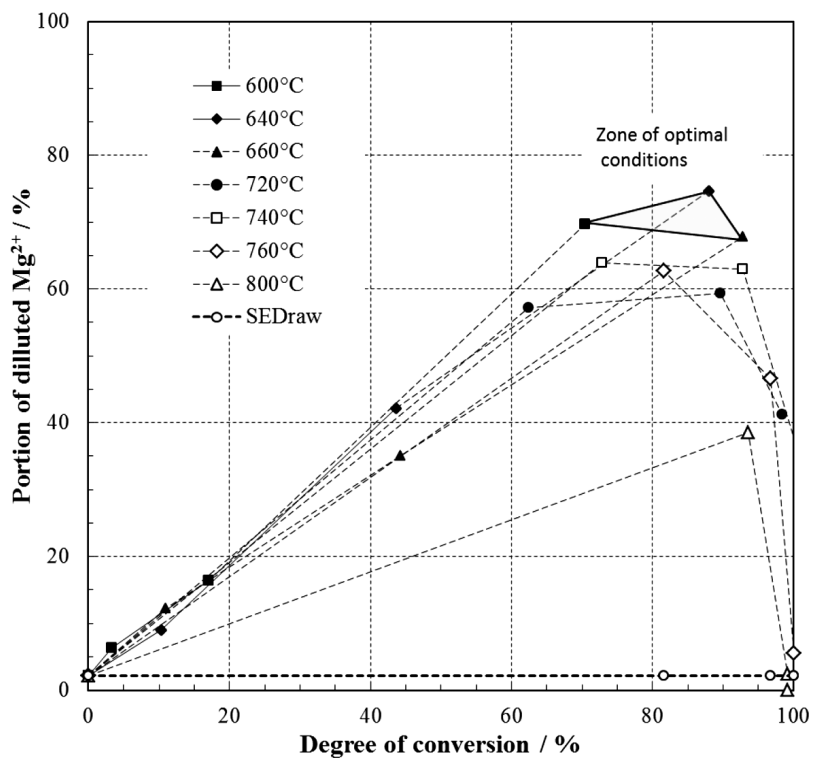

Figure 4: Dependence of the dissolution efficiency of magnesium depending on the calcination condition for serpentinite (SED)

Slika 4: Odvisnost učinkovitosti raztapljanja magnezija od pogojev pri kalcinaciji serpentina (SED)

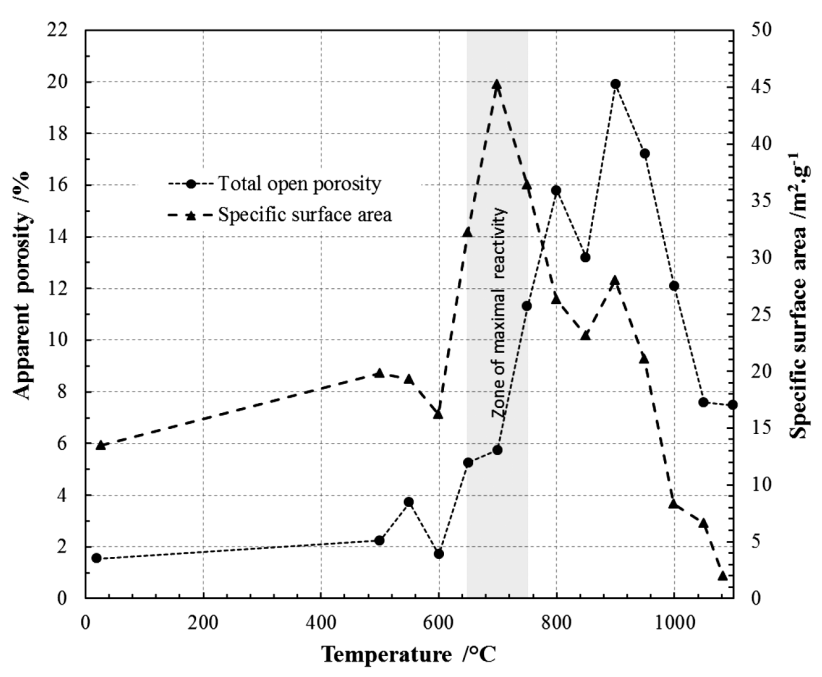

Figure 5: Comparison of the total open porosity and specific surface area as the function of temperature

Slika 5: Primerjava skupne odprte poroznosti in specifične površine v odvisnosti od temperature

of leaching, it is necessary to calcine serpentine so that a conversion of about $80 \%$ is achieved and the calcination temperature is in a range from 600 to $700{ }^{\circ} \mathrm{C}$. This will also guarantee the maximum surface area, which is an important parameter affecting the kinetics of the leaching. On the other hand, a porosity increase does not indicate a leaching improvement because of the structure stabilization due to the transformation to forsterite as shown in Figure 5.

\section{CONCLUSION}

The chemical reactivity of calcined serpentine depends primarily on the degree of structural crystallinity. The leaching rate of the forsterite-crystal phase is similar to the leaching rate of crude serpentine. It makes the thermal activation meaningless.

The reactive serpentine formation at temperatures of $600-700{ }^{\circ} \mathrm{C}$ does not significantly depend on the dwell time, unlike in the case of higher temperatures. At a temperature above $700{ }^{\circ} \mathrm{C}$, a partial forsterite formation takes place.

At the temperature above $700{ }^{\circ} \mathrm{C}$, the apparent porosity increases, but the specific surface decreases. This phenomenon is related to the recrystallization, the overall contraction of the volume and the sintering.

\section{Acknowledgement}

This work was supported by the Scientific Grant Agency of the Ministry of Education of the Slovak Republic and The Slovak Academy of Sciences - Grant VEGA 1/0378/14. 


\section{G. SUČIK et al.: THE RELATIONSHIP BETWEEN THERMAL TREATMENT OF SERPENTINE ...}

\section{REFERENCES}

${ }^{1}$ L. Haurie, A. I. Fernández, J. I. Velasco, J. M. Chimenos, J. M. L. Cuesta, F. Espinel, Polymer Degradation and Stability, 91 (2006) 9, 989-994, doi:10.1016/j.polymdegradstab.2005.08.009

${ }^{2}$ V. V. Velinskii, G. M. Gusev, J. of Mining Science, 38 (2002) 4, 402-404, doi:10.1023/A:1023324206554

${ }^{3}$ A. Pietriková, M. Búgel, M. Golja, Metalurgija, 43 (2004) 4, 299-304

${ }^{4}$ A. Fedoročková, B. Plešingerová, G. Sučik, P. Raschman, A. Doráková, Int. J. of Mineral Processing, 130 (2014), 42-47, doi:10.1016/j.minpro.2014.05.005

${ }^{5}$ R. A. Silva, C. D. Castro, C. O. Petter, I. A. H. Schneider, Mine Water - Managing the Challenges, IMWA 2011, Aachen, 2011, 469-473

${ }^{6}$ A. Fedoročková, M. Hreus, P. Raschman, G. Sučik, Minerals Engineering, 32 (2012), 1-4, doi:10.1016/j.mineng.2012.03.006

${ }^{7}$ A. Fedoročková, P. Raschman, Chemical Papers, 100 (2006) 5, 337-347

${ }^{8}$ W. Gao, J. Wen, Z. Li, Industrial and Engineering Chemistry Research, 53 (2014) 19, 7947-7955, doi:10.1021/ie4043533
${ }^{9}$ J. N. Weber, R. T. Greer, American Mineralogist, 50 (1965), 450-464

${ }^{10}$ A. F. Gualtieri, A. Tartaglia, Journal of the European Ceramic Society, 20 (2000) 9, 1409-1418, doi:10.1016/S0955-2219(99) 00290-3

${ }^{11}$ D. Hršak, J. Malina, A. B. Hadžipašić, Mater. Tehnol., 39 (2009) 6, 225-227

${ }^{12}$ C. Viti, American Mineralogist, 95 (2010) 4, 631-638, doi:10.2138/ am.2010.3366

${ }^{13}$ A. F. Gualtieri, C. Giacobbe, C. Viti, American Mineralogist, 97 (2012) 4, 666-680, doi:10.2138/am.2012.3952

${ }^{14}$ P. Raschman, A. Fedoročková, G. Sučik, Hydrometallurgy, 139 (2013), 149-153, doi:10.1016/j.hydromet.2013.08.010

${ }^{15}$ B. Plešingerová, K. K. Tkáčová, L. Turčániová, Transactions of the Technical University of Kosice, 4 (1994) 1, 79

${ }^{16}$ J. R. Günter, H. R. Oswald, Bulletin of the Institute for Chemical Research, Kyoto University, 53 (1975) 2, 249-255, [cited 2014-08-22], available from World Wide Web: http://hdl.handle.net/ 2433/76601

${ }^{17}$ G. W. Brindley, R. Hayami, Mineral Magazine, Pennsylvania, 35 (1965), 189-195 